\title{
Aspects of Intellectual Property Law for HEP Software Developers
}

\section{Lawrence S. Pinsky ${ }^{1}$}

Physics Department, University of Houston

4800 Calhoun Blvd.

Houston, Texas 77204-5005, USA

E-mail: pinsky@uh. edu

In the international arena of HEP software development, it is increasingly important for developers to be aware of the details of Intellectual property issues that not only can but almost certainly will affect them at some point, if it has not already done so. The traditional areas of Intellectual Property Law, which include Patents, Copyrights, and Trademarks, along with Trade Secrets, have all seen their share of modifications in the face of the advent of the Internet. The Internet has had both an operational impact and in some cases a substantive impact on the law. Let us not forget that the Web itself is from its origin HEP software. This paper will review these fundamental areas of Intellectual Property Law and try and point out where specific issues of interest to HEP developers lie.

XII Advanced Computing and Analysis Techniques in Physics Research Erice, Italy

3-7 November, 2008

1 Speaker 


\section{Introduction}

Let's begin with the concept of property. Normally when we think of property, we think of tangible things like your laptop, or maybe the land your home is on. Property is linked to the concept of ownership. One can "own" property, of course, but just what does ownership mean? Actually, ownership is typically measured more by what you can prevent others from doing than by what you yourself are allowed to do with the property in question. Think about it for a moment. If you own land, the most precious rights are the ability to keep others off than any list of things that you are allowed to do yourself on the land. Generally, we describe the rights that an owner of some piece of property as being like a "bundle of sticks," each right being separate and distinct, and more importantly, where each right can be individually given to another person without the owner having to surrender any of the others. For example, if I own a piece of land, I may give to my neighbor the right to pass over a designated portion of it briefly each day to reach a road on the far side. Such a grant to another person to exercise one of my exclusive rights in property that I own or control is called a "license."

If another person exercises one of my exclusive rights in some piece of property without a license, that is called trespassing, or an infringement on my rights. A license is a complete defense to a charge of trespassing or infringement. This leads us to another point. Exactly where do these property rights come from? Who decides what rights exist? In the most primitive societies (and unfortunately among the most civilized nations) "might makes right," and the strongest individual determines what rights exist. Otherwise the answer is that the government does. That is, we determine by law what property rights the courts will enforce. If someone infringes one of your property rights, the law of each country determines whether or not the police will enforce your right, or if you try and enforce it yourself (that's called "self-help" in legal circles) whether they will consider that it is YOU who have broken the law in taking such an action. So, property rights are determined by laws, statutes that is, and in most cases just what items are considered to be "ownable" is codified within each countries legal infrastructure. 
It is not surprising that there is some disagreement from one culture to another as to what things may be owned. For example, in some African tribal cultures the idea that an individual may own and bequeath to his or her heirs' real property (i.e. land) is totally foreign to them. ${ }^{1} \quad$ Rather, land is something that is owned by the tribe in common, and allocated temporarily to individuals during their lifetimes according to their needs. We will see that when it comes to IP, especially in the area of software, there is great disagreement even between advanced countries as to what rights should and should not exist.

When it comes to tangible things like real property and personal property (variously referred to as "personalty" or "chattel" like your iPod or your clothes), it is easy to view and understand the normal kind of exclusive ownership rights. For example, if someone steals my laptop, and I later discover it in some other place, if I can prove that it is my laptop (i.e that I never legally surrendered my ownership rights), generally I am entitled to recover it under the law without any need to establish who took it and regardless of how the present possessor came into possession of it. That is because it is never possible for anyone to give "better title" to a piece of property to someone else than the possessor has. In other words, If I do not possess a particular one of the "sticks" in the bundle of ownership rights in that piece of property, then I cannot possibly give it to someone else. That is an essential attribute of property rights that distinguishes them from "contract" rights. I may sign a contract with another person, and thus be bound by the provisions of the contract, but in most cases those provisions are not binding on any third parties who are not directly "in privity" of contract. That is, the provisions of a contract generally bind only the parties to the contract, whereas a property right is good against the world-at-large. ${ }^{1}$

How does all of this work when the property in question is intangible, like an idea? How does one own and idea? The answer is that it is just like tangible property in terms of the way in which the rights work. Intellectual Property (IP) is intangible, but nonetheless can possess almost the same bundle of rights that tangible property can. Classically, IP has been divided into four generic categories: Patents, Copyrights, Trademarks and Trade Secrets. In recent years there has arisen an attempt to create still

\footnotetext{
${ }^{1}$ Note that there is a "tort" called tortuous interference with a contract, which can reach an individual who knowingly tries to subvert the intention of a contract between other individuals.
} 
other rights, such as the new laws enacted in the EU creating property rights in the factual contents of databases. ${ }^{2}$

Virtually all countries have IP laws, and these laws are far more similar to each other than they are different. This is generally due to several major international treaties. The Paris Convention ${ }^{3}$ sets the standards for what are termed Industrial rights, which includes Patents and Trademarks. A treaty known as the Bern Convention ${ }^{4}$ covers copyrights. Both of these list minimum standards, which the signatories must grant under their laws. They also require what is termed "national treatment," which means that the rights of foreign nationals must at a minimum be the same as those afforded to the citizens of the granting country. Countries are generally permitted to give more than the minimum rights, which is where most of the disparities between different country's laws arise.

One overarching question to address before discussing the individuals types of IP in detail is why have IP at all? What are the possible motivations for a government to enforce such rights? Generally the rationales for IP fall into two categories, economic and moral. Both the US and UK base their IP laws on the economic rationale, namely that by giving protection to IP creators, they will be provided with an incentive to create more. In the end the goal is to balance the limitation on other's rights to use the IP for some fixed period of time against the ultimate right of society to inherit the information. In the interim, the owner can choose to make the IP available for a fee (called a royalty), and the net effect is to provide a maximum of useful IP to society for its use, as well as to maximize the production of new IP. IP owners are never required to license their rights, except that governments usually retain an absolute right to license any IP for their own purposes for the payment of a "reasonable royalty."

The continental European governments come to the rationale for IP rights from the moral perspective., namely that inventors, authors and artists have the moral and ethical rights to the exclusive exploitation of their respective creations. This moralrights approach is responsible for some important differences between the details of the respective laws crafted under these two rationales, a few of which will be pointed out along the way as we discuss the individual areas of IP law in more detail. 
One last point that is essential to keep in mind is that in general where there is more than one IP creator involved, there is joint ownership of the entire body, regardless of the relative quantity or merit of the individual contributions. This joint ownership is similar to a joint bank account, where one owner does not need the permission of the other owners to access any of the jointly owned resources. In some cases, however, an "accounting" of the use to the other owners may be required. The details of this accounting requirement differ from one jurisdiction to another.

This joint ownership characteristic of IP means that in general where collaborative projects are concerned, it is essential to consolidate the ownership rights into a single entity wherever possible. Typically this can be done by employment agreements such as those that are required to be signed by employees of many universities and national laboratories. However, may times, especially in the development of software for use in particle physics, a substantial number of contributors come from different countries with different laws governing the assignment of their rights, so particular attention must be paid to keeping clear records of the source and authorship of all contributions, and where possible to obtain an assignment of the rights in those contributions to some common entity. The detailed situation also differs from one type of IP to another as will be mentioned in the discussions that follow.

\section{Patents}

Patent law had its origins in Venice in 1474 with the world's first Patent Statue, ${ }^{5}$ which was remarkably similar to the current patent infrastructure. The motivation was economic in that it encouraged foreign inventors to come to Venice to teach the secrets of their inventions to the local artisans for which they would have the exclusive right to make, use and sell the inventions in Venice for a period of 20 years, after which the invention would become part of the public domain. The statute also provided to the patent holder a legal remedy against any infringers during the term of the patent. Modern patent law essentially provides the same provisions. The patentee is required to disclose all of the details of her invention in such a manner that it empowers anyone "skilled in the relevant art" to practice the invention. For that disclosure, the inventor gets a patent for the term of 20 years from the original filing date. The patent gives the 
patentee the exclusive right to deny others to make, use, sell, offer for sale or import the invention. It is very important to understand that the patentee does NOT get any specific rights to practice the invention herself.

Besides the detailed disclosure of the nature of the invention (called the "specification"), the patent application includes a set of very specific descriptions of unique details of the invention. Known as the patent claims, each claim effectively stands as a separate patent. Claims generally are composed of connected elements, schematically $\mathrm{A} \Rightarrow \mathrm{B} \Rightarrow \mathrm{C} \Rightarrow \mathrm{D}$. Patent applications must be novel. That means that it cannot be publicly known beforehand. There are specific lists of what kinds of existing information can be used as "prior art" to determine whether the invention is publicly known. Prior art can include publications or talks at professional meetings. Even a single discussion with another person without a covenant of confidentiality can be considered to have made the invention publicly known. Likewise, a single Ph.D. thesis in listed in the card catalog in a single university library can also suffice. ${ }^{6}$ In most countries, the invention must be novel at the moment the application is filed. This creates a problem because patents filed in other countries are considered a prior art, even if filed by the same inventor. Thus, a patentee would have to file simultaneous applications in every country that she wants to patent her invention in. Rather than inflict this burden on inventors, there is a Patent Cooperation Treaty (PCT) which holds that any application filed in a signatory country will be honored as of that same date when later filed within a specified time in another signatory country by the same inventor. That time period can be extended for up to 30 months in total from the initial filing. ${ }^{7}$

Novelty is determined by comparing the elements of the claims against the prior art. Any piece of prior art that a claim in the patent application "reads-on" (i.e. where the prior art has each element of the claim in question connected as described) is not novel. Thus a claim of $\mathrm{A} \Rightarrow \mathrm{B} \Rightarrow \mathrm{C} \Rightarrow \mathrm{D} \Rightarrow \mathrm{E}$ would be patentable over a piece of prior art characterized by $\mathrm{A} \Rightarrow \mathrm{B} \Rightarrow \mathrm{C} \Rightarrow \mathrm{D}$. However, even though the patent could issue, if there was a prior patent on a claim of $\mathrm{A} \Rightarrow \mathrm{B} \Rightarrow \mathrm{C} \Rightarrow \mathrm{D}$, then the owner of the new patent for a claim of $\mathrm{A} \Rightarrow \mathrm{B} \Rightarrow \mathrm{C} \Rightarrow \mathrm{D} \Rightarrow \mathrm{E}$ could be blocked from practicing her patent by the owner of the prior patent. Likewise, the new patentee could block the old 
patentee from adding the new element " $E$ " to his patent. This illustrates a case where a patent holder cannot practice her patent. IP rights tend to be of this sort, that is the right to deny others the opportunity to make use of the IP. Where multiple individuals collaborate on an invention, each is a joint co-owner of the patent (more on this later). To be a co-inventor, all one has to do is materially contribute to at least one element of one claim in the patent. In most countries, patent applications must be signed by all inventors.

For infringement one simply compares each claim of the patent to the infringed device, and if any claim reads-on the accused device (i.e. is has all of the elements connected as described in the claim, regardless of whatever else it may have), then it infringes that claim of the patent. It does not matter that the accused infringer did not copy or even know about the existence of the patent but honestly re-invented it himself. If any claim reads on it, it is an infringement, period. Note that the infringing item can be a completely different type of entity from that contemplated by the patent, and intended for an entirely different purpose, it only matters that embedded somewhere within the infringing item one can find all of the elements connected as described by at least one claim of the patent.

In addition to being novel, patents must be "non-obvious" or as described in Europe, they must include a significant "inventive step" over the prior art. That is to say that patents will not be given for trivial or obvious improvements to existing publicly known inventions. Just what constitutes a significant inventive step is essentially the major time consumer of patent attorneys and patent examiners. Patents must also be useful, which seems like an innocent enough requirement until one considers patenting molecules like the proteins which various sequences of DNA code for when the patent applicant has no clue what use that protein might be put to. Note that while you do have to declare a valid use, that declaration is not a limitation, and the claims can create infringements in any use no matter how far removed from the original patentee's ideas, so long as the claims read-on the accused infringing entity. Patents can be given for physical inventions (e.g. a mousetrap), for compositions of matter (e.g. drug compounds), or for methods (e.g. the process to produce a drug). Method patents 
have the steps in the process as elements. This seems like a description that could fit a computer program, doesn't it.

So far, the descriptions given apply almost universally. However there are some terribly important differences. For example in the US (and the Philippines), an invention does not have to be novel on the date of filing. Patentees have one year after they first publicly disclose their invention to file their application in the US. This leads to two other differences. Multiple inventors may file conflicting applications. In that case since there is no "first to file" rule, the US uses a "first to invent" rule. That is the first person to fully conceive of the invention in its entirety in his mind and then who diligently moves to file the application without any undue delay will get the patent. Just how one provides such evidence is another matter. The other difference is that if an inventor in the US publicly discloses her invention and then files the application in the US within the 12-month "grace-period" she would still have lost the patent rights around the rest of the world where absolute novelty is required. The famous RSA encryption scheme fell victim to exactly this situation. ${ }^{2}$ The authors presented their paper at an IEEE meeting, after which they were advised to patent it, which they did. The patent was valid in the US for the full patent term, but unpatentable in the rest of the world. We'll consider the conundrum of such inventions that manifest themselves on the web, later.

Perhaps the most important differences from one jurisdiction to another are concerned with what subject matter is and is not patentable. Generally, to be patentable the subject must have been invented and not discovered. As such, laws of nature or a naturally occurring thing cannot be patented. However, it is possible to include a physical law as part of an invention such as a process for curing rubber that uses a wellknown equation from thermodynamics in determining some of the steps in the process. ${ }^{8}$ Even more bizarre is US patent law, contrary to that of many other nations, allows the patenting of living animals such as a strain of bacteria designed to clean up oil spills. ${ }^{9}$ The patenting of the human genome is also a matter of some contention as well. The rationale used so far is that when the genes are identified, specified exactly and in an

\footnotetext{
${ }^{2}$ See e.g. http://en.wikipedia.org/wiki/RSA, for an excellent discussion of the history of the patent as well as a description of the actual mathematical process.
} 
"isolated and purified form," that this is somehow unnatural enough to avoid the discovery prohibition. ${ }^{10}$

In general, abstract algorithms cannot be patented, and in Europe this principle is employed to exclude patents on software per se. In the US it is possible to patent software if you include the computer executing the code as part of the claimed device or method (e.g. a process for figuring out how much tax is owed comprising a computer running a specified tax preparation program). This has led to the more or less routine patentability of software in the US, including CPU microcode. The debate now raging in Europe over the wisdom of allowing software patents is also circulating in the US as evidence mounts to support the suggestion that they have become far more of an obstruction than an incentive to the development of new software.

The potential pitfall here is the fact that in developing new software, it may be possible for the programmer to purely accidentally include embedded in her code all of the elements of some claim from one of the many of the obscure software patents, which remain in effect for 20 years. Remember, that the original application intended for that code in the patent is irrelevant. The only thing that matters is whether or not the claimed elements are present in the same relative way in the accused infringing code.

Another recent area of patent subject matter evolution has been the gradual allowance of patents for "business models" (as method patents) in the US ${ }^{11}$ with the staunchly opposing view in the EU. The celebrated case of Amazon and their patenting of the "one-click" method of doing business via a website is an example of this.

Finally, there is a dark cloud in patent law that is causing a lot of sleepless nights, among patent attorneys at least. That cloud is called the Doctrine of Equivalents. The idea is that an infringer should not be able to avoid liability for infringement by making subtle changes in some element that avoids literal infringement. This means that the reach of the patent claims is slightly broader than their literal meaning. How much broader? Well, courts have used various phrases like "insubstantial differences" but the fact remains that a court must decide each case. So, even though you do not literally infringe any of the claims, if a court decides that your accused infringement is too close to the claims, you can still lose. The strongest argument to keep such a doctrine is "after-discovered-technology." That is, where a 
patentee could not have anticipated the advent of technology, which allows secondcomers to avoid literal infringement in the latter years of the patents term. The leading example of this is a patent for stabilization of orbiting satellites by calculating the timed firing of onboard thrusters. At the time the patent was filed, computers were far too big to be placed on the satellites themselves, so the patent called for radioing down to Earth the sensor information where the computers would do the calculation and radio the firing commands back to the satellite. With the advent of smaller computers, the radio step in the process could be eliminated avoiding literal infringement of the original patent. The Doctrine of Equivalents was used to preserve the patents scope to include the onboard computer as still being an infringement. ${ }^{12}$

The use of patents to protect software is relatively recent. Rather, from the earliest days of software development, Copyrights have been the IP of choice for software protection. Copyright is in some sense a complementary form of IP to patents. Unlike patents, copyright protects against explicit copying, and independent creation is totally allowed. Copyrights specifically do not protect ideas, nor do they protect any of the utilitarian features of a creation. Instead, copyright protects the creativity of the author or artist. The archetype of a copyright protected work is literary work (i.e. a book). When computer programs first came into being, the printouts of the code for a program looked like a literary work, so the natural response of the IP law community was to treat it like literary IP. So, let's explore briefly the extent of copyright protection.

\section{Copyrights}

Copyrights as legal rights came into being because of technology, specifically the advent of the printing press. When the tedious process of manually copying books by hand was required to reproduce books, there was no worry about the potential exploitation of the creative work of another author because the effort of the scribe was so considerable. However, with the printing press, came the ability for one publisher to easily and quickly profit significantly by copying the work of others without paying for it. The first copyright law was the Statute of Anne in England in $1710,{ }^{13}$ and it provided protection for the publishers (i.e. printers) of books rather than for the authors 
themselves. Ever since that first technologically motivated movement of the law into the provision of copyright protection, it has typically been the advent of new technology that has spurred the legal system to react and revise the reach and scope of copyright protection. Because, virtually all copyright laws begin by laying out the scope of the type of works that are covered, when a new technology evolves, as did photography in the mid-nineteenth century for example, or phonograph records in the early $20^{\text {th }}$ century, copyright law must decide whether to provide protection, and if so, what the scope of that protection will be. The advent of computers and its latest appendage, the Internet, have both provided a significant impetus to the modification and expansion of copyright law.

While authors and publishers do register their works and put (C) notices on them, these are not a requirement for copyright protection to attach. The saying goes that "copyright attaches as the pen is lifted from the paper." Any copyrightable work is protected from the moment of its creation with no formalities required. Copyright applies to virtually all forms of authored creations from literary and artistic works to music and dance choreography. In some cases multiple forms of copyright are present in what seems to be single piece of work. Take a typical music CD for example. There is a separate copyright in the music by the composer, in the lyrics by the lyricist, in the performance by the singer, in the recording itself by the studio technician, and probably in the cover art by the graphic artist who designed it as well as by the author of any text printed on the $\mathrm{CD}$ or on the cover.

The default owner of the copyright is the creator herself. However, typically in jurisdictions where the rationale for IP rights is based on the economic incentive, there is a doctrine called "works-made-for-hire." When an employer specifically employs a person for the purpose of creating a copyrighted work (i.e. hiring a person to write a user's manual for a piece of software), then in those jurisdictions, the copyright in the resulting work is owned from its creation by the employer without any need for an assignment by the employee. Generally in those jurisdictions any copyrightable work produced by an employee "within the course and scope" of his employment falls within the ambit of the works-made-for-hire doctrine. In moral rights jurisdictions there is no comparable doctrine, so employers have to be sure to get their employees sign a 
contract (an employment agreement) which specifically assigns to the employer the copyright in any works created by the employee within the course and scope of their employment. In the case of patents, there is no comparable doctrine, and only the actual inventors may apply for the patents, so in all jurisdictions employers must obtain employment agreements requiring the assignment of all rights to any patentable inventions that they may make within the course and scope of their employment to their employers, along with their agreement to actually sign any relevant patent applications. The earlier remarks on collaborative works apply here.

So, once a work has been created, what rights does the copyright owner have? The basic right, which gives its name to this general type of IP is the right to make copies. The copyright owner can prevent others from making copies of the work, or at least the protected portions of it. Recall that copyright protects only creativity, so it is only that portion of the work that is protected. Clearly, if one copies the entirety of a work, then that would be an infringement because all of the embedded creativity would have been copied. However, if the copier only extracts unprotected portions, such as something that is utilitarian (i.e a menu structure in a user interface), or factual content, then that is permitted.

Since copyright protects only the creativity embodied in a work and not any of its utilitarian aspects, how does this affect replicating the functionality of a copyrighted program like say Microsoft Windows? Courts have wrestled with the problem of how to extract the creativity from the functionality in a computer program. Certainly, viewing the way a program functions in terms of its physical manifestations and then sitting down and writing from scratch an entirely new code to duplicate as closely as possible the functionality of original program, is generally permitted. Some aspects of the original program's features may be protected as creative, such as decorative color choices, etc., but where such choices merge with functionality, the copyright scope of protection wanes. If one does something more than just observing the gross properties of the executing code, such as by reverse engineering the structure of the code down to the level of the subroutine structures and replicates that as well, then it becomes a closer question. $^{14}$ Copying the actual code line-by-line is of course an infringement. However, if one separates the individuals who look at the original code and then 
abstract it into function elucidating "pseudo-code," which is turned over to "sterile" programmers (ones who have not actually ever seen the original programs detailed code), but who then write their own fully implemented version of the code, it is possible to avoid copyright infringement. Of course this is one of the reasons for the growing popularity of software patents.

Note that generally, the copyright owner cannot control the use that a purchaser of a bona fide copy of the work makes of it. If I buy a copy of a book that has been produced with the permission of the author, the author may not control the physical uses I make of that book, such as using it to hold up a short leg on a table or giving it to a friend when I am finished with it. I cannot make a copy of the book, of course, and this is a crucial point for software. Courts have ruled that loading software from a harddrive into RAM on a computer is copying the program. ${ }^{15}$ So, to use software as a practical matter the user must copy it, and to do that legally, you need a license from the copyright owner to exercise his exclusive right to make copies of the work. A license is a contract, and a contract can specify any reasonable terms. Because software can only be used with a license, the copyright owner has a vehicle unlike any other form of copyrightable subject matter to control the use the licensee makes of the software. Note that if the copyright owner sells the user the software, he loses that control, but if he merely grants the user a license with strings attached, then he can maintain the control. If you do not like the strings, then you should not accept the license, but if you do accept the license (usually by clicking the "I Accept" box at some point), then you have agreed to be bound by its terms. Microsoft never sells software; they only license it with conditions, many limiting conditions...

The GNU license is an interesting example of the use of copyright law to subvert it through licensing. ${ }^{16}$ In the Open-Source movement, the idea is to produce software that is more or less free of the nominal copyright restrictions for subsequent users. To accomplish this, the software is actually licensed under copyright law where the ability to control uses is employed to keep that software from ever being incorporated as part of fully protected software in a derivative work, and to "infect" any work that does incorporate any part of it, requiring that the entire new work be subsumed within the GNU license. This movement is sometimes referred to as "Copyleft." Other 
restrictions such as having to incorporate the notices of the restrictions and the attribution of the source are also included. There is a continuum of possibilities, some examples of which are the less invasive restrictions of the BSD Unix license. ${ }^{17}$ Lawrence Lessig, a professor at Stanford, has championed the Creative Commons approach to provide a range of license agreements that allow software developers (and other copyright owners) the ability to pick and choose what restrictions they want to impose on the subsequent users and developers. ${ }^{18}$

There are many other rights associated with copyrights than just copying. Perhaps the most important for software developers is the right to make "derivative works." The usual concept of a derivative work is making a movie based on a book. In the case of software, it can be any obvious extension of the work. There is a limit to the reach of this protection in that if the new work is sufficiently "transformative": then it may succeed in morphing into a wholly new work, free from the control of the copyright in the original. Remember that ideas are not protected by copyright.

Another exclusive right of the copyright owner is the right to publicly perform or display the work. If you buy a CD, you do not have the right to play it in a public place. There are "collective Societies" like ASCAP and BMI whose sole purpose is to license public performances of the copyrighted material produced by their subscribing authors and performers. Likewise, if you by a copy of a recently written play in book form, you do not have the right to perform the play in public. That would require a separate license from the author. Note that there is a popular misconception that if you personally do not profit from the infringement, then it is OK. This is absolutely wrong for all types of IP infringement. The issue is always, did the accused infringer exercise one or more of the exclusive rights of the IP owner without a license.

The Internet is a very interesting source of problems for this public performance or display right, along with the derivative work right. If I make a web page publicly available there is an implied license for visitors to my site to download and view my content on their compute screens (the license is required to copy the webpage to their computer. However, there is no implied right to print out a hard copy of that page or any of its content. Doing so in the absence of an express license, would be an infringement. One subtle problem has to do with hyperlinks. Since I can create a web 
page that incorporates content from another site in the Internet, I can make something such as a graphic image from someone else's site appear on my page when it is loaded by another user on her own computer. Because I only give that person the address to go to where she can retrieve the content in question, and I never actually copy the content myself, I am not liable for direct copyright infringement. However, the webpage that is viewed can be considered a derivative work, the making of which is an infringement, and if I induce another person to do that, then I can be liable as a contributory infringer.

Several rights that are recognized as part of copyright in Europe, but not in the US because of their "moral rights" nature are the right of "attribution" and the right of "integrity." The former is perhaps the greatest sin that an academic professional can commit, while it is not even a protected right in the US for all practical circumstances. It does exist in Europe. The right of Integrity is the right to prohibit the buyer of a legal copy of your work from defacing it or changing it in some manner. In a famous case from Germany, an artist was commissioned to paint a mural on wall bordering a formal staircase. The painting had some unclad female figures in it, which a subsequent home owner objected to, and so attempted to paint clothing over them. The artist sued and the court ruled that while the new owner had the full right to tear the house down, he did not have the right to deface the picture. ${ }^{19}$

As noted before, patents must be formally applied for and if granted, then their term extends from the date of issue to the $20^{\text {th }}$ anniversary of the original application date. Fees are required for the application, at issue and periodically during the term. Patents are valid only in the issuing country, and must be applied for separately in each country where protection is desired. Copyrights persist for far longer, generally for the entire life of the author, and then for an additional 70 years after her death. In the case of works-made-for-hire, the term is 75 years, and as noted, copyrights exist automatically from the creation of the work, and there are no required fees. In the US, one can register copyrighted material for a modest fee, and for US citizens, doing so allows them to qualify for some additional rights such as "statutory damages" should there be an infringement case. Non-US citizens qualify without the registration requirement because of the provisions of the Bern Convention. 
In cases of copyright infringement, the damages are usually in the form of a court order to cease and desist from continuing the infringing activity, as well as an award of any actual monetary damages that may have been suffered by the copyright owner due to the infringement. Statutory damages are available at the discretion of the court, which are intended to discourage small individual infringing activities that would otherwise be monetarily unprofitable to pursue. Currently in the US the court can award up to $\$ 10,000$ per infringement. The threat of this has been used recently in the US by the music industry to fight on-line piracy by suing individuals who are caught downloading copyrighted materials illegally for the statutory damages, which could be as much as $\$ 10,000$ per downloaded song. In contrast, patent infringement damages, besides court orders to stop the infringing activities, are usually actual monetary damages from lost sales or lost licensing fees. In both patent and copyright cases, the infringing materials as well as any items used to further the infringement are subject to confiscation and destruction. In cases of on-line music piracy, this typically means confiscation of the computer hardware used by the infringer.

Finally, in the case of copyright law, there is a special doctrine that legally grants people the right to infringe. It is called "Fair-Use." In special cases for things that the law considers worthy enough, individuals are allowed to exercise some of the exclusive rights of the copyright owner without permission. Should the copyright owner choose to sue for infringement, the user may offer Fair-Use as a defense in lieu of a license. Much of the Fair-Use doctrine is motivated by free speech or freedom of the press principles. For example, a book reviewer may quote small passages from the book being reviewed without a license from the author. Likewise, great deference is given to the use of materials in face-to-face education in the classroom. This does not mean that one can avoid paying for textbooks, but rather that where getting a license is not practical due to time constraints, or the refusal of the author to grant a reasonable license, the Fair-Use defense would apply.

Perhaps the most famous case invoking Fair-Use was the lawsuit by the entertainment industry against Sony in the early days of home video tape players (VCRs). ${ }^{20}$ The industry wanted to suppress the sales of VCRs or to collect a tax on their sales to offset the anticipated losses by the industry in the presumed massive infringing 
activities that would likely occur. The court ruled that while some infringing activities were possible, that there were also clearly many legal uses for the devices and that taping TV shows off of the air for later viewing (referred to as "time-shifting") was a Fair-Use. In retrospect, this was probably the most ill-advised action by the movie industry in its history, given the subsequent rise of the home movie rental business based on the wide availability of inexpensive VCRs to the public. The lesson in this is that one cannot always foresee the full impact of seemingly threatening new technology when it first emerges, and the political power of entities like the entertainment industry can be very counter-productive.

Like the Doctrine of Equivalents in patent law, one does not know beforehand whether the court will grant a Fair-Use exception in a particular case. Courts are given a set of factors to consider including: the nature of the use, the nature of the work, the amount of work taken, and the impact of the infringement on the copyright owner. So, while Fair-Use exists, it can still be uncomfortable to apply if the copyright owner persists in taking the matter to court. This uncertainty aspect of Fair-Use tends to reduce its usefulness considerably because in most cases the copyright owners are in a stronger financial position than the user, and the threat of legal action is often a sufficient enough discouragement.

Fair-Use has had a significant impact in the software world. In a case where the accused infringer wanted to produce and market games of their own original design for the copyright owner's game system, which employed special cartridges to provide the software for each the different games, the competitor needed to know the interface details. Naturally, the copyright owner, wishing to suppress competition and or collect royalty fees from other game designers, refused to disclose the needed information. So, the defendant in this case admitted to purchasing legal copies of the game cartridges, and reverse-engineering them to determine the interface specifications. This act was prohibited by the express license terms of the acquired cartridges, and in order to access the information on them, the defendant had to copy the code off of them, which was a direct infringement of the copyright. The court ruled that where there was not other way to do so, and for the purpose of interoperability of different software systems, the needed acts were indeed a Fair-Use. The principles espoused in this case became 
widely incorporated in the Fair-Use doctrine around the world, and was used to defend Jon Johansen in the famous case in Norway where he broke the DeCSS encryption scheme used to protect the content of commercial movie DVD's, and published the first Linux-based DVD player, something that the movie industry had refused to license.

Subsequent to this setback, the entertainment industry in the US had the Digital Millennium Copyright act passed which provides that any act intended to circumvent a copyright protection technology is per se illegal. Technically this is not about copyright infringement itself, because no infringing act is required to run afoul of this law. The mere act of circumventing the protection scheme, or for example publishing a written article merely describing how a scheme works can be actionable by itself in the total absence of any actual infringing activity. This act was used to suppress the distribution by websites in the US of Linux-based DVD player programs making use of the DeCSS technology. Of course, the law does not reach outside of the US, so sites beyond the reach of US law can and do still distribute such programs.

Another relevant application of the Fair Use Doctrine has been by the Internet search engines. When they display small samples of the text or thumbnails of pictures from the listed selections resulting from a search, these would in principle be copyright infringements. Because of the uncertainty as to just what is actually included within the scope of the Fair-Use Doctrine, the search engine owners typically do not press the issue, and when site owners object, they maintain that while they have the right to do it, they will "voluntarily" respect requests to exclude the objected content from their search engine displays. More about search engines later.

\section{Database Protection}

Historically, there have been cases where the courts have ruled that where someone invested a lot of time or money in producing something like a factual database, that the investment somehow made it protectable under copyright law where it would otherwise not be. This "sweat-of-the-brow" doctrine was resoundingly dismissed in a famous case over telephone books. ${ }^{21}$ A publishing company wanted to produce a phone book that included the numbers of subscribers over a collection of small rural telephone companies, each of which published its own separate directory. The publisher contacted 
the companies and offered to pay for a list of the names and numbers. One of the telephone companies refused, so the publisher copied the names, addresses and phone numbers as published in that company's own directory. The phone company sued, and the case went to the US Supreme Court, where the decision stated loudly and clearly that copyright protected creativity and not facts, no matter how much investment had been made in determining the facts. Facts are facts and not protectable under copyright law.

This decision sent a shockwave through the database industry in this burgeoning era of on-line of electronic databases. The problem is the following. While I can use contract to protect my electronic database by insuring that everyone I grant access to has agreed not to further distribute it, this contract restriction does not extend to parties who are not directly bound by the contract. If someone who has agreed to the contract breaches that agreement and turns over to an innocent third party the extracted content of my database, I can sue the person that I have a contract with, who might not have sufficient resources to cover my losses, when the third party puts up his own database using the facts extracted from mine.

In Europe, the argument was made that this fear was suppressing the development of a database industry comparable to the one that existed in the US. So, the EU government enacted a sui genris (i.e. new) form of IP protection in database content. $^{22}$ The idea was to give a property right in the factual content of databases to the individual who has invested sufficient resources in assembling the database. The point being that the database owners would "own" the facts in their database, and thus could reach any third parties, irrespective of any contractual relationships who had obtained the facts from the database. This is not an absolute right to the facts, as there is no exclusivity. Anyone is free to obtain the facts separately and then to disseminate such separately obtained facts without restriction. However, if the facts came from a protected database, then the database owner possesses the rights to control the use and distribution of those facts.

One of the very first cases to be decided under this new EU Database Protection law was the ownership of data about football matches in the UK. ${ }^{23}$ A football league sued betting parlors for listing the dates and places of matches and the teams involved in 
their shops for their customers use in placing bets. The league claimed that this factual information was assembled by them at sufficient expense to qualify for protection under the new law, and that it was undisputed that the only source for such facts was the league itself, so it did not matter how the shops got the facts, the league owned them and could require a payment for their use by the shops. The league won the case initially, but more recently in a similar case on horse-racing the European Court of Justice ruled that the Database Protection Law did not apply in either situation. ${ }^{24}$ So the situation is still evolving.

Similar legislation was introduced in the US, but at this time that initiative is essentially dormant. The potential problem for such legislation for the academic world is the need for the free and open access to factual information. While the economic IP rationale of providing an incentive to collect and distribute more facts with the protection than would be available without the protection has been suggested, there is little of no evidence of the net benefit of this legal infrastructure in the academic community, and the threat of the negative impact of such restrictions to access and use over the long run are more worrisome. Consider the following hypothetical situation.

Newton's gravitational constant, "G," is the presently the poorest known fundamental constant. There has been a proposal to improve our knowledge of $\mathrm{G}$ by an order of magnitude. The technique calls for building a special submarine apparatus and carefully measuring the acceleration of gravity as a function of depth as it descends in the middle of the Pacific Ocean. The cost of such an endeavor would clearly qualify the resulting information under the current EU law. Supposing this experiment is done, then the database in question would contain one decimal digit. Under the current law, the owners of that database could license the use of that information under contract to any interested parties. Note that as long as that is the only experiment that has been done, then anyone in the world who comes into possession of the information unquestionably got it from ultimately from the protected database, so it would remain under the control of the database owners, who could dictate the royalty terms for its use including in doing calculations in one's head. This hypothetical presents an interesting question in the case where the digit measured turns out to be zero! 


\section{Trademarks}

Having discussed the two major areas of IP law, patents and copyrights, that impact software developers, let us not forget the relevant issues of Trademark Law. Trademarks have their origin in the guild-marks that craftsmen used to place on their products. Trademarks themselves have been around since trade itself began, and again, the earliest European "Trademark" laws were enacted in Venice around 1400 to protect "Guild-marks." 25 The idea was to identify the source of a particular good so that the consumer would have confidence in the quality of the product. The fundamental underlying principle of trademark law is consumer protection, and not necessarily the protection of the trademark owner's rights. However, in practice it is the trademark owner who possesses the rights and who pursues infringers in the name of protecting the consumers. The basic issue in trademark law is "likelihood of confusion" on the part of the consumer. That is, does a confusingly similar mark serve to confuse the consumer as to the origin of the good in question?

Unlike the other areas of IP law we have discussed, trademark law is strictly about trade. That is it applies to goods and services for sale in the marketplace. Trademarks can only exist when there are goods and services to apply them too. In principle one cannot "warehouse" a trademark without having goods or services actually available in the market place. Recently, provisions for obtaining trademarks in advance of the actual marketing of the goods have been provided for, but only for very short periods of time. Trademarks are fundamentally specific to a type of good, and before the Internet at least, to a geographic region.

One recent modification to trademark law that defers to the trademark owners is the introduction of the concept of dilution. When a mark becomes famous (e.g. Coca Cola, Cadillac, etc.) then the mark can be protected against most other uses, even when there is no confusion and the products do not compete (e.g. Cadillac Cat Food would have been prevented from using the name Cadillac, even though consumers would not be likely to confuse it with a car manufactured by General Motors).

A trademark can be anything that is used to associate a product with a manufacturer. Logos and names are obvious, but they can also include colors, characteristic shapes (e.g the classic "Coke" bottle) and even the overall "trade-dress" 
appearance of a business like McDonalds or Starbucks. Like copyrights, trademarked characteristics cannot be used to prevent competitors from using functional features. Also, when a trademark becomes so successful that it is adopted by the public as the generic name for the general class of product itself, the trademark owner loses the exclusive right to the mark. "Aspirin," which was Bayer's original trademark name for acetylsalicylic acid became generic and is now usable by all drug makers. Xerox has had to battle to keep the use of their mark from becoming a generic term for making copies of documents.

Trademarks do not expire arbitrarily. That is they do not have any specified term, and remain valid so long as they are in continuous use associated with a marketed product or service. Trademarks expire if they are not used (typically after 5-years of non-use), or as described above, if they become generic. In most jurisdictions you are required to register a trademark, and the application for registration is subject to a search for potentially confusing similarity with already registered trademarks. Unfortunately, like patents and unlike copyright, one has to register a trademark in every jurisdiction where you want protection.

Trademarks can be even more powerful then copyright to prevent copying. In the fashion industry, while clothing designs cannot be copyrighted (that is just a tradition which is arbitrary), manufacturers have learned to incorporate their logos into their fashion articles (e.g Louis Vittuion's LV logo, Channel's interlocking C's, etc.) so that copiers will be infringing trademark law by making exact copies, whereas in the absence of the trademark protection, there would be no prohibition.

In the software development world, the trademark issues are modest at best, but can appear. While you might be able to copy Microsoft Windows functionality, you could not include the Windows trademark, and possibly even there default color schemes. For webpage design more issues can arise. While copyright protection may not cleanly protect against linking items on one web page to content from another, if the linked material includes a trademark, then protection under trademark law would kick in and make the linking an infringement. This was used to prevent the marketing of a web page that used frames to provide convenient links to major news sources while posting banner ads around them. ${ }^{26}$ 


\section{Internet Law}

At one of the very first conferences on Internet Law in the mid-1990's, a famous US Federal Judge and legal expert, Easterbrook, gave the keynote address. ${ }^{27} \mathrm{He}$ basically told the participants to go home, that there was not such thing as "Internet Law" any more than there had been a "Law of the Horse." This comment was a reference to a famous remark by Oliver Wendell Holmes, the Supreme Court Justice, referring to the then current idea that there was a separate "Law of the Railroad." Holmes actual remark was "There is no more a Law of the Railroad than there is a Law of the Horse..." What Holmes and Easterbrook meant is that the fundamental principles of the law are universal and independent of any application area like the railroad or the Internet. However, in recent years as the legal systems have had a chance to come to grips with some of the unique aspects of the Internet, it is not so clear that there aren't some new and different principles that needed to be incorporated into the law.

Some examples that have strained the application of pre-existing legal principles will suffice to illustrate the point. Search engines have created challenges to the law in many areas in addition to the interpretations of their employment of the Fair-Use doctrine in copyright law as described earlier. Sometimes site owners want to exclude them for anti-competitive reasons. In one case a search engine designed to provide comparisons of current bid-prices on competing auction sites like eBay, was sued because it was directing business away from the more popular sites. The auction sites won the case when the court decided to consider that the search engines were "trespassing" to the property of the auction-site owners. Consider the comparable situation in the case of physical stores like supermarkets where one storeowner has the right to enter the publicly accessible areas of his competitors store to ascertain the prices at which he is selling his goods. Clearly, that kind of activity is in the public interest and supports the fundamental principles of the market economy. Apparently, the courts have decided to treat the Internet differently.

Another issue that has arisen is that when one posts something on a publicly accessible website, it is viewable all over the world, and as such it is subject to the restrictions and moral judgments as well as the IP laws of every jurisdiction 
simultaneously. An early but illustrative case actually predates the Internet. A couple in San Francisco, ran a dial-in site providing "indecent" material for download at a price, paid for by credit cards. Everything they had on the site was publicly available in San Francisco and in fact they had submitted it to the local prosecutors who ruled that it was "merely indecent" and not "pornographic." Legally, "pornography" is illegal where "merely indecent" material is not. The problem is in determining where to draw the line between the two. In the US, the law is based on "local standards." What is considered "merely indecent" can (and generally is) different in San Francisco than it is, for example in conservative rural Tennessee. In a sting operation, a postal inspector in Tennessee called into their site in the middle of the night and downloaded 10 carefully chosen pictures. Once the downloads were completed, police, who were waiting outside of the couple's apartment arrested them. They were extradited to Tennessee and tried there for distributing pornography. They were convicted and served a jail sentence. In that case, because they could be extradited, they were vulnerable to prosecution in a distant venue for doing something that was entirely legal where they lived. ${ }^{28}$ Imagine, the potential for international travelers to be arrested as they pass through distant lands for perceived IP infringements by things posted on their websites at home.

Another issue, which is not local to the Internet per se, is on-line identity verification. In conducting transactions one has to decide whether a digital signature will be accepted to bind the remote alleged party. A moment's thought will lead you to the conclusion that in all cases of trying to verify an individual's identity, one has to find some trusted third party who is in a position to know the absolute identity of the person in question. This is as true in the real world as it is in the virtual one. In practice it is the government that is the guarantor of identities in the real world by issuing birth certificates and passports (although in the US the very insecure use of driver's licenses is the most common form of identification). Ultimately too in the virtual world, governments will have to serve the same role. Private entities can do the bulk of the actual work, but ultimately they will have to be certified by the governments via secure links. The systems are evolving, and efforts are underway to make them operate as 
closely to the physical world as possible. The advent of "Certificate Authorities" is a manifestation of this philosophy.

While strictly speaking it is not Internet Law, one related issue is the recent advent of Preprint Servers in the world of Scientific Publications, and the rise of the electronic distribution of articles by the conventional print-based peer-reviewed journals. As most academics are aware, you are generally asked to surrender all copyrights in any article you agree to allow to be published by these journals. That assignment typically includes the rights to copies residing on the Preprint servers as well, which leads to the frustrating situation where once an article is formally published, you have to pay to download what was available for free a short time ago. Publishers are well aware, by the way that old copyright assignments executed without specific inclusion for the right to distribute copies electronically, do not include that right by default. In a recent case, authors of submitted articles to the New York Times sued and won additional royalty compensation for the on-line distribution of their works by the Times as part of its normal publication of web-based archival copies of the newspaper. ${ }^{29}$

\section{References}

[1] David E. Ault and Gilbert L. Rutman, “The Development of Individual Rights in Property in. Tribal Africa," Journal of Law and Economics 22(1), 162-189 (1989).

[2] See The Directive 96/9/EC of the European Parliament and of the Council of 11 March 1996 on the legal protection of databases.

[3] See e.g. http://www.wipo.int/treaties/en/ip/paris/.

[4] See e.g. http://www.wipo.int/treaties/en/ip/berne/trtdocs_wo001.html.

[5] See e.g. http://www.experiencefestival.com/patent_-_history_of_patents.

[6] [Ph.D. Thesis as Prior Art-Ref here...]

[7] See, e.g. www.wipo.int/pct/en/texts/articles/atoc.htm.

[8] See Diamond v. Diehr, 450 U.S. 175 (1981).

[9] See Diamond v. Chakrabarty, 447 U.S. 303 (1980).

[10] See e.g. http://www.ornl.gov/sci/techresources/Human_Genome/elsi/patents.shtml.

[11] See State Street Bank \& Trust v. Signature Financial Services, 149 F.3d 1368 (Fed. Cir. 1998).

[12] See Hughes Aircraft Co. v. United States, 717 F2d 1351 (Fed. Cir. 1983). 
[13] See e.g. http://www.copyrighthistory.com/anne.html.

[14] See e.g. Computer Associates Int'1, Inc. v. Altai, Inc., 775 F.Supp.544, 549-55 [20 USPQ2d 1641] (E.D.N.Y. 1991).

[15] See Mai Systems Corp. v. Peak Computing, Inc., 991 F.2d 511 (9th Cir. 1993).

[16] See www.gnu.org/copyleft/gpl.html.

[17] See http://opensource.org/licenses/bsd-license.php.

[18] See http://creativecommons.org/.

[19] See Entscheidungen des Reichsgerichts in Zivilsachen 397, [1912] Droit D’Auteur 9.

[20] Sony Corp. of America v. Universal City Studios, Inc., 464 U.S. 417 (1984).

[21] Feist Publications Inc v Rural Telephone Service Co Inc., 113 L Ed 2d 358 (1991).

[22] See The Directive 96/9/EC of the European Parliament and of the Council of 11 March 1996 on the legal protection of databases; or http://en.wikipedia.org/wiki/Directive_on_the_legal_protection_of_databases.

[23] Case C-46/02 Fixtures Marketing Ltd v Oy Veikkaus Ab [2005] ECDR 2, ECJ,

[24] British Horseracing Board Ltd, Jockey Club, Weatherbys Group Ltd v William Hill Organization Ltd (CA) 13.7.05.

[25] See e.g. William H. Browne, A Treatise on the aw of Trademarks, 1-14 (1885)

[26] See e.g. Jeffrey R. Kuester and Peter A. Nieves, Hyperlinks, Frames and Meta-Tags: An Intellectual Property Analysis, 38 IDEA: J.L. \& Tech. 243 (1998).

[27] Cyperspace and the Law of the Horse, Frank H. Easterbrook, 1996 U Chi Legal F 207, Available at: www.law.upenn.edu/law619/f2001/week15/easterbrook.pdf.

[28] United States v. Thomas, 74 F. 3D 701 (1996). The 6th U.S. Circuit Court of Appeals. See e.g. http://www.eff.org/pub/Legal/Cases/AABBS_Thomases_Memphis.

[29] New York Times Co. v. Tasini, 533 U.S. 483 (2001) 206 F.3d 161, affirmed. Syllabus, Opinion [ Ginsburg ], Dissent [ Stevens ], Available at: www.law.cornell.edu/supct/html/00-201.ZS.html. 